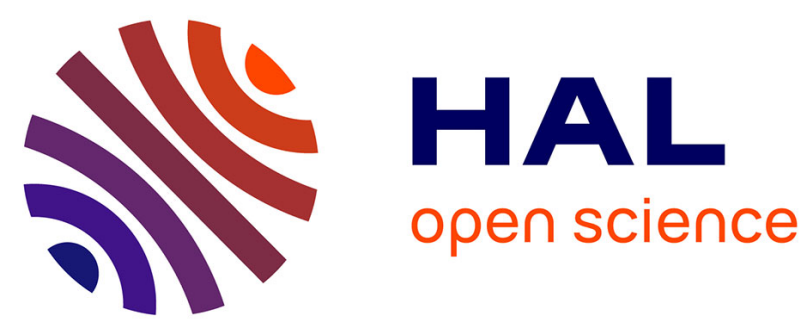

\title{
The reconstructions of Beirut
}

\author{
Joe Nasr, Éric Verdeil
}

\section{To cite this version:}

Joe Nasr, Éric Verdeil. The reconstructions of Beirut. Salma K. Jayyusi, Renata Holod, Attilio Petruccioli and André Raymond. The City in the Islamic World, Brill, pp.1116-1141, 2008, Handbook of Oriental Studies, 10.1163/ej.9789004162402.i-1500.299 . halshs-00261149

\section{HAL Id: halshs-00261149 \\ https://shs.hal.science/halshs-00261149}

Submitted on 6 Mar 2008

HAL is a multi-disciplinary open access archive for the deposit and dissemination of scientific research documents, whether they are published or not. The documents may come from teaching and research institutions in France or abroad, or from public or private research centers.
L'archive ouverte pluridisciplinaire HAL, est destinée au dépôt et à la diffusion de documents scientifiques de niveau recherche, publiés ou non, émanant des établissements d'enseignement et de recherche français ou étrangers, des laboratoires publics ou privés. 


\section{The Reconstructions of Beirut}

The City in the Islamic World, Brill, Leiden

Joe Nasr, independent researcher, associated with the Institut Français du Proche-Orient,

Beirut, Lebanon

Eric Verdeil, CNRS, UMR 5600 Environnement Ville Société, Lyon, France

\section{Introduction}

Beirut has successively been seen as the icon of the war-destroyed city, the paradigmatic case of "urbicide" 1 and then as the symbol of a city rebirth through the reconstruction of its city center, ${ }^{2}$ praised in real estate journals and sold as a booming touristic destination to natives of the Arabo-Persian Gulf. Both images place Beirut as a city out of compare, out of norm, defining it as a unique and extraordinary city. Such exceptionality should nevertheless be challenged. On one hand, the city as a field for local and global wars - and its consequent reconstructions - is a fate that Lebanon's capital city has shared with Jerusalem, Baghdad, Hama (and almost Aleppo), Mogadishu, Sarajevo, Mostar, Belfast, among many others in the late $20^{\text {th }}$ century. ${ }^{3}$ The war-torn city is an extreme case, considered from the point of view of urban violence as well as from that of urban planning. Urban violence and planning must then be analyzed as conscious tools for reshaping urban societies and nations in the hands of various political actors at the local, regional or global scale. The city has to be re-placed within political, socio-demographic and economic turmoil in its gradation and in the steps onwards and backwards from peace to war. Reconstruction then has to be considered as a series of moments in a political balance of power. On the other hand, in certain ways, urban policies related to reconstruction differ only in degree (rather than in kind) from planning and projects intended to transform the city in more common frameworks. Instances can be found in the general attitude of contempt by many planners for the ancient urban fabric and its inhabitants, be it in the name of the modernization of the city, the affirmation of the state or the necessary adaptation to economic globalization.

The dual image of Beirut as war city versus as rebuilt city is also false because there were multiple reconstructions of Beirut and because of the intricate connections between destructions and reconstructions. First, Beirut has experienced over time several experiences of reconstruction, not only in time of war but also, due to Ottoman then French projects of modernization, in the aftermath of World War I. During the more recent war, the distinction between the time of destruction and the time of rebuilding itself is not clear since the reconstruction's projects were a factor of destruction or at least demolition; and the failure of peace agreements during the Lebanese war at least twice interrupted the fledgling reconstruction processes. The attempts at transformation, even if many failed, have left imprints, both in legal constraints and property patterns (launched expropriations, approved decrees that were not implemented...) and in the mentalities and memories of various actors. Considering those failures and their effects thus offers new light on the rebuilding processes.

\footnotetext{
${ }^{1}$ Perhaps the best-known example of journalistic analysis is Friedman's From Beirut to Jerusalem (1989).

${ }^{2}$ This is exemplified in the title of a book from the 1990s, Beirut Reborn (Gavin and Maluf 1996).

${ }^{3}$ It is thus not by accident that an international conference on the rebuilding of postwar cities was held in the 1990s in Beirut. The proceedings are found in Tabet (1999).
} 
Our entry point in this paper is the physical reconstruction of the city, as a way to highlight reconstruction in its broader meaning: ${ }^{4}$ the physical reconstruction takes place in a political and socioeconomic framework shaped by the war. Other policies of the post-war context relate to displaced people, reconciliation, or deal with specific sectors (roads, energy, etc.) at the scale of the country; these choices interact with the reconstruction projects. The reconstruction in itself should not be seen as a linear process. Feedback effects are altering the implementation and changing the initial designs.

Understanding Beirut's reconstructions first requires a brief overview of the history of transformations in the Lebanese capital city before 1975. Wartime Beirut and its plans then provide an understanding of the radical changes that affected the city and of the failed reconstructions. The plans and projects of the postwar era, with an emphasis on the city center, will lastly be analyzed.

\section{A Brief History of Transformations in Beirut before 1975}

\section{From a provincial Ottoman town to the capital city for a new state}

While Beirut remained, until the mid- $19^{\text {th }}$ century, a small provincial Ottoman town, a range of political transformations progressively changed its status. ${ }^{5}$ The development of trade with the West was favored through a range of decisions: the creation of the quarantine, then the transformations of the harbor and the construction of the Beirut-Damascus road. Closer connections with the Mount Lebanon hinterland developed, particularly through silk production and commerce, although that district was administratively autonomous under the status of muttassarifiya. Numerous Christian refugees settled in the city after the massacres of 1860 in Damascus and in Mount Lebanon. The creation of the wilaya (governorate) of Beirut in 1888 gave the city a new administrative status. During the $19^{\text {th }}$ century, Beirut's population and trade grew at the expense of those of Saida and Tripoli. After World War I, the French chose Beirut as the capital city of the states of the Levant and of Lebanon, a new state whose borders were extended beyond those of the Mount Lebanon muttassarifiya, in order to include the Bekaa Valley, the city of Tripoli, the Akkar plain as well as Jabal 'Amil in the hills overlooking the plains of Palestine, which stood under the authority of the British. Beirut thus gained control over territories that used to be in closer relationships with other cities, like Damascus for the Bekaa or Haifa for Jabal 'Amil. As for Tripoli, the new border cut it from its own hinterland and the cities of the Orontes basin in central Syria.

After World War II and the national independence of Lebanon in 1943, Beirut was able to take advantage of a range of political and economic transformations that helped foster its regional role. The creation of the state of Israel and the Arab-Israeli war of 1948 led to the closure of Haifa's trade with the Arab countries. Beirut's harbor was reinforced as the main one along the Mediterranean coast, with its hinterland extended to Iraq and the Arabian Peninsula, under the impetus of the oil-fueled boom in commerce. In 1951, the breach of the free trade agreements between Lebanon and Syria meant that the proponents of a 'Merchant Republic' imposed their view of the country as a commercial link between East and West.

\footnotetext{
${ }^{4}$ On the multiple understandings of reconstruction in Beirut, see Nasr (1999). Some of these understandings are developed in other articles in the book where that article is found.

${ }^{5}$ A number of publications now exist on the urban history of Beirut, including its physical transformation. See for instance: Kassir (2003), Davie (2001) and Tabet (2001).
} 
During the fifties, Beirut benefited from escapees from the nationalist and socialist revolutions in neighboring countries, from the influx of rich Palestinians, and from those who made fortunes from oil incomes from the Arabic-Persian Gulf, all of whom brought in their wealth into Lebanon's banking system and invested in its real estate sector. The policies of banking secrecy and free trade were vital pull factors. Beirut and Mount Lebanon became a touristic center starting in the sixties. Western firms settled their regional offices in Beirut, where they found the security of a pro-Western government, a skilled population, an attractive atmosphere and an airport from which all Middle Eastern destinations could be reached. Beirut's regional role thus relied on the rise of a service economy for the whole region.

The economic prosperity of the Lebanese capital city did not reach all regions of Lebanon, and this discrepancy was a main factor in rural migration, but the flows of refugees resulting from the multiple regional political conflicts also were a major contributor to demographic growth. After World War I, Beirut received Armenian refugees from Cilicia (southern Anatolia). After 1948, it was the turn of the Palestinians. Economic migrants from rural Syria were also numerous. As a consequence of those migrants' waves, Beirut's population grew from about 160,000 in 1920 to 400,000 in 1950. In 1970, the city and the first ring of suburbs amounted to 800,000 inhabitants but the whole agglomeration pushed the total to 1.2 million.

Indeed, the small Ottoman city had experienced major physical transformations. Since the 1930s, the city had spread beyond the municipal boundaries and absorbed the nearby villages of the plains and hills surrounding the town into suburban nuclei. The typology of buildings was altered through the spread of the concrete multistory building. The settlements' patterns also became more complex. A new business center developed in Hamra, west of the ancient city center. Informal settlements and refugee camps were built in the suburbs. Partially planned subdivisions were established on the hills outside the city.

\section{The construction of a capital: Plans and projects}

The emergence of Beirut as a capital for a new state and as a regional center, along with its associated physical transformations, were the result of political and economic external choices as well as unexpected regional changes. The new status took place in the broader framework of the modernization of cities, either inspired by the Ottoman Tanzimat (reforms) or, later, by the diffusion of town planning ideas in the colonial world. The desire to modernize the city and to adapt it to its new status and role certainly came from outside but it also met the desire of part of the local elites. Staging the new Lebanese nation has been another intricate dimension of urban projects in Beirut since the end of the nineteenth century. The building of a new state has to be represented in stone in the new city. Over the past century, however, conflicts were always present around the implementation of such projects. The balance of power never allowed the successive national government to fully achieve their ambitious features. The local institutions - notably the municipality, established in the 1860s, then after 1920 controlled by the French, later marginalized by the government in independent Lebanon - could not be considered particularly powerful actors. Other players, such as landowners including religious foundations (awqaf), and corporate interests, should also be mentioned here.

The "ottomanization" of the city, under the auspices of the municipality and the walis (governors), from 1878 until World War I (Hanssen 1997), included a range of projects. Among them, the redesign of the Burj Square with the new Serail (1883-4) and the erection of a clock tower (1898) reflecting Istanbul time, were representative of the spirit of the time (figure 1). In 1915, a long-delayed project of modernizing the souk area was launched. Some 
of the demolitions had taken place when the French arrived in town after the war. One of their first concerns was then to complete it, before they progressively extended, transformed and redesigned it. The area near the harbor was designed on an orthogonal grid and its main streets were named after Foch, Weygand and Allenby, the victorious generals of World War I. Designed in 1925-26 and implemented until the end of the 1930s, the Place de l'Etoile superimposed its branches on the old ottoman urban fabric. The plan faced harsh resistance by the Christan awqaf and two of the branches were never implemented. ${ }^{6}$ The national institutions like the Municipality or the Parliament buildings were designed according to a new "Levantine" architecture. These first modernization projects of Beirut's center bore both continuity and change in planning. Change is evident in the new scale that the French gave to the project or in new regular patterns like the new star design. But continuities appeared in the modernizing project itself, or in the modus operandi through the municipality. The Levantine architecture, intended to exalt the new state of Lebanon, was drawing at the same sources as the "Ottoman" one and was designed by the same local muhandissin (engineers and architects) that were in charge previously, like Youssif Aftimos.

The introduction of modern planning outside old Beirut in the thirties (Ghorayeb, 1996) was less successful, and from the years of Independence until the civil war, the Lebanese government experienced many similar disappointments. During the entre-deux-Guerres, French colonial cities became an experimentation field for the planners, at the request of the colonial authorities, with Morocco and Syria, to various extents, emblematic of such methods. In Beirut, a first attempt occurred in 1930-32, by the brothers Danger whose firm, La Société des plans régulateurs de villes, had operated elsewhere in the Near East. In the context of war, in 1941-43, Michel Ecochard, the young architect who had established the town planning administration in Syria in 1938, was commissioned for the task of setting up a master plan for the expanding city and modernizing parts of the city center where governmental administrations had to be built. Both attempts failed in the face of real estate speculation, the interests of private French corporations (like the harbor or railways companies or the Banque de Syrie et du Liban) as well as the financial weakness of the public actors.

At Independence, the project of planning and modernizing Beirut was caught in the tension between two imperatives: the development of the national economy and the affirmation of the state. During the 1950s, the plans remained modest, in line with the official laissez-faire policy of the Merchant Republic. The main efforts consisted of building a new airport in Khaldeh, adapting the legal framework to real estate pressures, and widening some major arteries, according to the plans adopted after the drafts by Ecochard and the Swiss planner Ernst Egli (figure 2). After the civil riots that took place in Lebanon in 1958, Fouad Chehab was elected President. He stressed the reform and modernization of the state in order to unify the country. Balanced development across the Lebanese regions and control over the growth of the capital city were identified as key goals. Thus, town planning, now firmly in the hands of the central government, became a major field of concentration; consequently, a law was passed in order to introduce new planning tools. ${ }^{7}$ The creation of a directorate for urban planning, in 1959, and of two independent public bodies for the implementation of projects, in 1961 and 1963, was a significant proof of the government's determination.

Once again, Ecochard was hired. In 1961, he had been commissioned to establish a master plan for the governmental cities (a large administrative complex) outside the city center, reflecting the will to reform and rationalize the administration. In 1963, Ecochard submitted a

\footnotetext{
${ }^{6}$ On the response of local notables, see Davie, 2003.

${ }^{7}$ Verdeil, 2003. See also part of Rowe and Sarkis, 1998.
} 
master plan for Beirut and its suburbs. It integrated the idea of an urban deconcentration towards new cities linked to the agglomeration by a network of freeways. The city center was to be widely renovated with high-rise buildings and separate circulation according to the Modern Movement principles (figure 3). This project combined the concern for real estate and economic development in a city intended to become a bridge between the West and the East, with the objective of the symbolic affirmation of the state, since several sites were dedicated to public buildings. A new legislation on mixed real estate companies was set up for the implementation of the project. But the Chehabist plans were only partially implemented. The zoning ordinance (though modified under the landowners' pressures), the road network and a few administrative buildings in the governmental city of Bir Hassan, were the main achievements, whereas public housing and new town projects as well as the renovation of the central district were all abandoned, because of the change in the balance of power in the country after the end of Chehab's mandate in 1964 and the financial impacts of the regional crisis of 1967.

Because of its status of capital city of a new and unsteady state, planning and modernizing Beirut was always related to the building of the nation. While the attempts at modernizing the capital city, and particularly the city center, also aimed at fostering an economy based on regional trade and real estate, the projects were always connected with episodes of political reconstruction and of state affirmation, but they also aimed at fostering an economy based on regional trade and real estate.

\section{Wartime Beirut and its Plans}

\section{War as context for urban change}

The war, from 1975 until 1990, was a complex framework for urban change. The intricate dimensions of the war (international, regional and local; ideological and religious) are a first specificity. It makes the Lebanese situation different from the case of the European cities during the Second World War in terms of the temporality and spatiality of fighting, the nature of destructions, the identities of protagonists (organized armies or militias) and their nationalities (Lebanese, Palestinian, Israeli, Syrian, Iranian, American, European, etc.) and the stakes of the war (religious, social, related to the local scene or to the regional one). Because of its length, the actors on the scene seriously changed over time. The state and its administrations were greatly weakened: they were now even less able to control urbanization in terms of, for instance, construction licenses. Moreover, the administrations usually were not able to retain and to replace their skilled workforce, which worsened the situation. Ruined, displaced, absent, or wary of undertaking repairs, landowners were also directly or indirectly hit by the war. Conversely, new actors emerged or became prominent. A range of individuals and groups benefited from the war economically or politically. The chiefs of various militias even became ministers or officials. Certain businessmen also profited from the wartime economy. The rise of Rafiq Hariri, based in entrepreneurial successes outside Lebanon (in Saudi Arabia), illustrates another aspect of the political and financial renewal. In the state administration, the Council for Development and Reconstruction (CDR), created in 1977 to replace the Ministry of Planning, gradually concentrated a lot of powers at the expense of the obsolescent 'classical' administration. 
The Lebanese war is in fact more a succession of "rounds" with different stakes involved, separated by episodes of "peace" that did not succeed, mainly in 1977 and in 1982-83. The cyclical nature of war is the reason why destructions and reconstructions were intertwined. Almost all the country has been affected by the combats, at least during one round, and at least indirectly. Beirut and its suburbs have been one of the major and continuous scenes of the war, which thus deserves the qualification of an urban war. The demarcation lines in Beirut remained over the war's course remarkably stable. The city center also was one of the main places of confrontation. The interactions between these different factors were accompanied by urban transformations that can be considered according to their various scales.

\section{Multiple scales of Beirut's wartime transformations}

The war hit the city hard. The damage was not only physical: the spatial organization of the population and the means of production were also transformed. People coped in various ways, using the countryside and the secondary towns as places of refuge. But the country as a whole and Beirut specifically underwent an economic marginalization. The most immediate cause was war damage itself. Evaluating the destructions is a challenging methodological issue. ${ }^{8}$ Buildings that were seriously or totally damaged are estimated, in Greater Beirut, at over 10\% of buildings. The numbers hide geographical differences (figure 4): inside the municipal boundaries of Beirut, this amounted to about $16 \%$ of destructions; but in the city center, almost all the buildings were hit to some extent, and along the demarcation line, serious damage has been evaluated at $80 \%$. Still, the level of destruction in Beirut remained below the widespread destructions that befell some European cities like West Berlin, where $25 \%$ of buildings were destroyed. In contrast to the heavy damage from air bombing (including associated firestorms) and tank fights, the most destructive weapons in Lebanon were relatively small rockets or missiles.

More typical of civil and urban wars, the population was affected by massive moves. Exodus from the provinces to the capital and cross-flows of refugees between different areas of the city radically altered the geographical distribution of populations. In 1987, about $27 \%$ of the inhabitants were considered refugees, not including all those who had "freely" moved for safety reasons. The most notable result of those shifts was the formation of two sectors with relatively homogenous religious composition on both sides of the demarcation line: the East was almost totally Christian while the West was largely Muslim. Another consequence has been the rapid and massive expansion of the suburbs, particularly along the northern coast and in the hills, as well as in the southern plain. Most buildings were built following regulations, but illegal or unpermitted land occupation or construction was common, notably in the southern suburbs, mostly occupied by Shi`a refugees or migrants (Clerc, 2002; Fawaz, forthcoming).

The withdrawal of multiple functions (housing, industry, commerce...) and at multiple levels (towards the countryside, towards the secondary towns of Lebanon, and towards villages near Beirut) partly compensated for the destructions and insecurity in the capital. The ratio of Greater Beirut's population in Lebanon fell from about 54\% to 42\% between 1970 and 1996. The emergence of agglomerations like Jounieh, Zahleh-Chtaura or Nabatiyeh illustrates this mechanism that reduced the place of the capital in the country.

\footnotetext{
${ }^{8}$ Some of these challenges are discussed in part of Nasr, 1997.
} 
Furthermore, the regional place and role of Beirut and Lebanon were deeply affected by the war. Although partially compensated through the return incomes from the Lebanese diaspora, including those who had fled abroad recently, the loss of GDP, expressed in constant value, reached about 25\%. Several key economic sectors were severely hit: some left Lebanon, like the offices of Western firms, banks and other financial establishments, while others had to close, like the hotels and the tourism sector. The Beirut harbor and airport, both major infrastructures of the Lebanese development system before the war, were out of order during most of it. Meanwhile, other cities were able to attract the fleeing firms and to adapt to the economic changes in the region. Amman, Dubai, Manama, Doha, Cairo and other cities developed new functions: airports, finance and bank sectors, universities, hospitals. Some of the roles that Beirut used to play before the war were simply no longer relevant, competitive or unique, as the cities above and many others became centers that fulfilled most of Beirut's former basic functions. The Lebanese capital had thus become marginal within its own region.

\section{Wartime plans and projects}

The brutal destructions and transformations of the city, particularly in places that had high symbolic and economic value like the city center, made physical reconstruction an imperative. Conceived as a tool for the recovery, the projects aimed at not only recreating the conditions of economic development of the pre-war time, but at modernizing a historic core that was increasingly seen as decrepit, obsolescent, in need of transformation. This implied that the reconstruction projects would use the opportunities made available by the war to implement some plans and ideas that were previously facing obstruction, such as the modernization projects in the city center or the metropolitan restructuring plans. The war thus would give more relevance to older agendas, whose memory was not lost.

If references to the prewar situation and projects were evident in many plans, the reconstruction was and is, in certain respects, a process of consolidation of the war changes, such as the various confessions' polarization on both sides of the demarcation line or the expansion of the city towards the mountains. This is particularly relevant for the political renewal: the reconstruction was crucial for establishing the legitimacy of new political actors in charge during the two episodes of reconstruction and reestablishment of the state, in 1977 and in 1982-83 (Verdeil, 2001).

At the end of the two-year war (1975-77), President Elias Sarkis designated the economist Salim al-Hoss as Prime minister. Amin al-Bizri, an architect and a former president of the Order of Engineers was put in charge of the Ministry of Public Works. With a professional committee, he personally supervised the reconstruction plans for the center of Beirut that a French public consulting firm, the Atelier parisien d'urbanisme (APUR), was setting up. The proposal dealt with a vast perimeter of 120 hectares including the main damaged sites. The center was a symbolic place since it was the major public space of the city, where the different communities of the country interacted. The first proposal was to restore the image of a Mediterranean city. It included the restoration of the souks, the opening of the city to the harbor, and the design of a promenade along the sea. It suggested a limitation of the building heights to $30 \mathrm{~m}$ and vituperated against the "international architecture". It was indeed the first time that the heritage problematique was applied in Beirut. But the second side of the project was the modernization of the city: it foresaw new public buildings symbolizing the unity of the state. It also included new arteries through the ancient urban fabric, as well as the realization of a modern business center on an old dock site. In order to foster business development, it called for doubling the total floor area of the most damaged areas by the 
erection of new buildings. The 1977 plan's main justification was the pressing need to go back to normalcy of the prewar period and to revive the image of a united state and of a Mediterranean city devoted to trade. In line with prewar projects, these objectives also sought to foster businesses, to develop the real estate and to open new arteries in this area.

The progressive failure of the peace arrangements did not allow the implementation of the projects, and the new fights worsened the damage in the city center. Reconstruction reflections only resumed in 1982, in the aftermath of the Israeli invasion, when the Phalangists Bachir and then Amin Gemayel successively acceded to the Presidency. The latter did not have the legitimacy of his brother nor his political support. The reconstruction process offered him an opportunity to build it. His strategy was not limited, as had been the case in 1977, to the city center. He launched a broad program, including several new laws, emergency actions in the city center and in the southern suburbs, a massive project of urban development with sea reclamations on the northern shore of the agglomeration and a master plan for the metropolitan area of Beirut, whose consultant was the French Institut d'aménagement et d'urbanisme de la région Ile-de-France (IAURIF). The city center, once again, was seen as a symbol of the continuity of the Nation. But the extension of war damages, combined with the fact that the St George bay had become, from 1978 on, a dumping site requiring major reclamation, made it necessary to alter the previously adopted planning scheme. OGER, a contracting firm belonging to the businessman Rafiq Hariri, offered its help and was in charge of clearing the site. Under unclear circumstances, it demolished wide parts of the ancient souks near the Burj Square, clearing far more than just war-damaged structures. Between 1983 and 1986, OGER on its own introduced several amendments to the official plans and proposed various options (figure 5). As a result, the reconstruction plan was radicalized. It called for a modern architecture, densification of the project and development of commercial, touristic and business functions, at the expense of heritage conservation and of the old landowners and tenants. In fact, it accepted and affirmed the social changes resulting from the fighting.

In the southern suburbs, the state was facing the question of illegal settlements in an area that was politically controlled by the Shi'a militias of Amal and Hezbollah. The attempt at solving the real estate problem was initially combined with a project of low-income housing and infrastructure upgrading in various parts of the locality (Verdeil, 2002a). But the brutal removal of several squats, in the framework of resuming tensions between the President and his Shi'a opponents, led in February 1984 to an uprising that plunged once again Beirut into war. As for the northern projects, they were intended to restructure a partly derelict industrial region into a touristic and residential neighborhood. This took place in the Metn, the place of origin of President Gemayel who personally supervised the project (Verdeil, 2002b). The transformation of this area would not have been conceivable without the social change in it, as it turned from an industrial district to a commercial and residential one, in the framework of installation of Christians fleeing West Beirut.

Both projects, for the southern and northern suburbs, illustrate that planning was not a neutral reaffirmation of the state; rather, it expressed a balance of powers as well as it consolidated the social transformation affecting the city. It should be noted that Rafiq Hariri was involved in both projects and increasingly in the city in general, as a contractor and an investor, which is not without importance for the next stages of the reconstruction processes. The last project was the metropolitan plan. It stressed the unity of the city through the rebuilding of the city center and a network of public transport means. In order to avoid an uncontrolled urban sprawl, it proposed secondary centers in Nahr el Mott, Hazmieh, Laylaki and Khaldeh. 
Although the master plan was established with much less political interference than the other projects, the siting of these centers was later questioned because their location in the Christian, Shi'ite and Druze territories was interpreted as an acceptance of the division of the city into belligerent sectors.

These plans have been very incompletely implemented, although they would influence the postwar future of the areas concerned. Uncovering such an archeology of planning ideas and concepts sheds light on long-term processes and continuities in projects. Among the key actors, the professional planners can be mentioned as bearers of the memory of ideas - though the inflections and alterations they bring to plans cannot be ignored either. The actions of political and economic actors also are essential, particularly when their careers rest so heavily on planning interventions, as the case of Hariri illustrates perfectly.

\section{Postwar Beirut and its Plans and Projects}

\section{New scene, new stakes}

Rafiq Hariri, once and again the prime minister (1992-1998 and 2000-til today) - and prime investor - of Lebanon, has been the dominant character in the next phase of this story: the postwar years, since 1991. He exemplifies the enduring interpenetration of public and private interests, the linkages between urban planning policies and affirmation of political clout, and the continuity in actors in the city-building (or city-destroying) process during and after the war (having had a wartime role in beginning to reshape the city's townscape, then expanding this impact after the fighting stopped). Some influential actors of the war era, such as expresident Amine Gemayel, largely disappeared from the scene, while others appeared. As a consequence of the transformation of the political and administrative framework, important changes occurred in the professional milieus in charge of the reconstruction. Returning emigrants, young western-trained architects and engineers, and consulting firms originating in Lebanon which had grown into regional firms while based abroad (the largest being Dar al Handasah-Shair and Partners), have designed or undertaken most of the reconstruction projects.

One significant shift compared to the war era was the reemergence of the state as a central actor (or actors), even if it was as permeated as ever by private interests. Despite this important caveat, the negotiations that had taken place leading up to the Ta'ef Accord that paved the way for the stoppage in combats at the end of 1990, meant that it was through the careful and continuous balancing act of political representation across confessions and other groups, that the governing of the reconstruction was to take place. This gave the state, through its key structures (particularly the CDR), the prime role in the recovery of the country, as an actor itself, as a channel for foreign influences, ultimately as an arena for negotiations among various actors.

Because one key stake in such negotiations was the access to state funding (and international funds flowing through the state), the postwar era was generally characterized by profligate spending on "hard" projects. As such, the physical reconstruction was at the heart of the overall reconstruction process, and was to have major consequences on the course this would take over time. Moreover, this spending was twinned, particularly in the early 1990s, with the reinforcement of the vibrant consumerist lifestyle for which Lebanon was long known. This 
coupling of high levels of public and private spending was to have great repercussions on the entire Lebanese economy over time.

As can be read from the above observations, the past dozen or so years that so far make up the postwar era did not form a single, stable period, but displayed rather an evolution that reflected and resulted from the general course adopted for the country's recovery. Hence, this recovery - for Lebanon and in particular for Beirut - consisted of a series of false starts, of successes and failures, of miscalculations and adjustments. Overall, one can observe a general trend from an early boom and optimism, followed by a gradual loss of steam through stasis, and ultimately a crippling of the country's progress. This trend in the country's recovery was reflected in (and to a certain extent caused by) the rebuilding of Beirut itself. It will be discussed in three phases that broadly characterize these twinned histories (Huybrechts, Verdeil, 2000).

\section{Three phases of Beirut's postwar transformations}

\section{Phase 1: Private boom and groundlaying of public projects (1991-1994)}

The first few years after the fighting stopped were distinguished by an almost immediate spike in the level of construction activity in Lebanon. Within metropolitan Beirut, this activity at first maintained the expansion of the fringe areas even when Beirut became "safe" again; but within a short time, Beirut began to recover, as demolitions, repairs, rebuildings, all took off. This was clearly the result largely of individual initiatives in those early years, on a case-by-case basis, in a very haphazard way. This rediscovery of Beirut as a locus for real estate investments did not throttle the investments in its periphery (many already under way since the 1980s), it was complementary to it at first. The highest levels of construction activity, around 1994, were thus reached before the full apparatus of the state was in gear.

The state attention in these years was in fact spread across a range of efforts; the state itself did not involve itself much in major infrastructural activity, though it worked on the planning for such activity. Instead, its focus in this phase was in emergency mode: beginning to assist refugees financially in relocating themselves out of squatted apartments, repairing basic utilities, restarting state services and administrations.

Some of this activity was not without controversy. But apart from the great public debate with international echoes - over the future of Beirut's central district which will be discussed below, many other parts of the country's recovery (whether the physical reconstruction outside this limited district, or the many aspects of the country's reconstruction beyond those of the physical rebuilding) received generally little debate, if they were not thoroughly ignored. One example was the priority given to new freeways at the expense of the revival of public transportation. So in the shadow of the towering question of SOLIDERE, the laying of the ground for countless other activities that occurred in parallel went on fairly quietly, while many other dimensions of the postwar recovery escaped any planning by the state.

Phase 2: Economic slowdown and implementation of public projects (1995-1998)

This phase may have represented the peak of the reconstruction era while, at the same time, it displayed the first signs of the "normal" activities of post-reconstruction times, even within Beirut. After a few years of preparations, many major projects went into full gear. Notably, 
the SOLIDERE company had been established by the government after overcoming the range of contestations over its existence and modalities, and it began to implement some of the major components of the transformation of Beirut's center: completion of the ring road, laying the roadways and its underlying infrastructure, renovation or recreation of much of the built fabric in the "historic" sectors within it, stabilization of the vast wartime maritime landfill... In parallel, the most significant public works projects were under construction or completed in these few years, particularly a number of new highways (the new airport road, the highway to the south, the doubling of part of the highway to the north, the bypass of the Damascus road...).

On the private side, dynamic construction activity persisted, though at a reduced pace. The continuing reemergence of Beirut as a magnet for large and small construction projects, mostly on the upper end of the market, was maintained. By this time, most of the activity consisted of ordinary projects, mostly redevelopment of older and smaller building sites throughout the city; construction to replace war-destroyed structures by now amounted to only a fraction of the construction activity. A distinctive type of residential highrises even became recognizable for certain common features (oval balconies, extensive use of marble and granite...). To accommodate these towers, the rash of demolitions, including of a number of buildings that had been placed on official protected lists, ironically went on simultaneously with the spread of renovations of equally historic buildings, particularly to accommodate trendy entertainment spots in some of the neighborhoods closest to Beirut's center. Hence, the contradictory parallel trends that appeared in the immediate aftermath of the war were crystallized and reinforced. The "banalization" of the postwar activities could also be seen in the linkages across the metropolitan area. While the profound Christian/Moslem residential split of the metropolis was not reduced at all, the movements across the area including across the line of separation line continued to be reinforced, serving at a limited level at bridging the contacts among individuals, even these linkages generally did not get any deeper: in other words, greater propinquity rather greater connectivity.

The most worrisome trend for the everyday life of the Lebanese and Beirutis, however, was the progressive economic slowdown that was to grip the country and city year after year. While some of it may be considered simply as the wearing off of the boom that is often inherent to many postwar eras, part of it has to be seen in the context of the sharp shift from regional optimism to pessimism that spread across the entire region subsequently to the assassination of Yitzhak Rabin across the border to the south. Indeed, the regional optimism had coincided with the local optimism that surrounded the very first years of the halt in combats in Lebanon -anticipating in particular an influx of individuals (emigrants to the Arab and Western countries) and funds (from these emigrants, from other Arabs, and from a mass of other foreign investors). This optimism evaporated fairly fast in the mid-1990s. However, while these explanations (even if illusory) were all exogenous, at least as important were the endogenous factors behind the slowdown in the economic machinery of the country that gripped it inexorably within barely four years of the beginning of the postwar era. Here, it has to be emphasized that the points in the two previous paragraphs, which seem contradictory of the ones in this paragraph, are in fact closely linked to them. Indeed, the endogenous explanations for the slowdown partly lie in the persistent spending by the state on massive infrastructure projects (including the rebuilding of the center as adopted) that it may no longer have afforded - if it ever did - in the changed regional climate, combined with the relentless investment in a construction sector on the private side that was not directly connected to specific levels of need and affordability in the country at the time. Hence the physical 
reconstruction (or construction) in Lebanon could not be separated from the negative trends from 1995 onwards in the country's broader reconstruction.

\section{Phase 3: Economic recession and end of the "reconstruction" (1999-2004)}

This phase is very much an extension of the previous one, with an affirmation of most of the trends that had emerged during those transitional years, a corroboration of the end of the postwar boom and undoubtedly of the "reconstruction" period as such. The economic slowdown turned here into a full-fledged recession, crippled by a spiraling level of public debt (165\% of the GDP in 2003), combined with a reinforcement of the blurring of the lines between public interest and private gains and a general lack of faith among potential investors. The forced exit of Hariri from power after President's Lahoud election lasted only a couple of years (1998-2000) and did not result in a reversal of the downhill slide of the country - nor did his return to power either. Whatever indications exist of a possible recovery in the past year or two (largely seen in an expanding tourism sector, with more than 1 million foreign visitors in 2003) relate to much more recent factors (especially the complex regional aftermath of the September 11, 2001 events) than to ones associated with the short-lived postwar economic recovery.

The consequences of this confirmation of a listless economic future for the country (Debié et al., 2003) - as reflected in the dramatic expansions of poverty and migration ${ }^{9}$ - are multifarious. Among others, many of the larger public urban interventions were either slowed down or deactivated. Construction activity has become very erratic, and the sight of cranes has become somewhat less common than it had been in past years. Still, deflation in many real estate prices did not result in a halt in construction activity, reflecting the sway of the myth of an unshakeable real estate sector. Nor does the decades-old focus on Arab visitors and investors appear under any threat - to the contrary, it is thriving, as reflected in the continuing erection of massive hotel/resort complexes.

Finally, some trends, first noted in the previous phase, do seem to be strongly confirmed in this period. One is the relative reinforcement of local powers, as seen particularly in the development of municipalities as genuine actors with some actual capacities following the 1998 elections (though their actions remain limited because of state control and funding scarcity). Another significant trend is towards the rehabilitation of the existing urban fabric. The massive success of the new-old Etoile, Maarad and Foch-Allenby zones in the heart of the area controlled by SOLIDERE as the prime destination for nightlife and more recently retail in Beirut would have to be placed among a series of other steps of recognition and usage of existing structures. These steps include some expansion in the reuse of historic buildings beyond the immediate pericentral zone; the façade painting efforts of the Help Lebanon charitable organization, which seems to be spreading to individual actions; the similar effort by the public Fund for the Displaced, shifting its priority from provision of fixed sums to the displaced to improvement of the image of some of the neighborhoods with a remaining refugee presence like Ras al Naba'; the new activities in old neighborhoods such as Gemmayzeh's "Arts Stairs” festival; and the large World Bank funding for a program that is twinning "cultural heritage" and "urban development" in Tripoli, Baalbak, Sidon, Byblos and Tyre.

\footnotetext{
${ }^{9}$ In 2001, 42\% of the households were earning less than 800,000 LP (about 500\$) on a regular monthly basis. About 400,000 Lebanese are estimated to have emigrated after the war, among whom about 250,000 during the years 1996-2001. Kasparian, 2003.
} 
Over the course of the past decade and a half, a series of seeming contradictions have emerged: simultaneous demolitions and rehabilitations, adjacent massive investments and untouched war ruins, parallel inexorable economic slide and unrelenting public and private construction spending... The brief explanations above sought to shed some light on how so many contradictions could be understood in the specific context of the Lebanese reconstruction and post-reconstruction years. These contradictions could be clearly seen in the plans and projects that were proposed and partially realized in this period.

\section{Postwar plans and projects}

The most basic aspects to note about the postwar reconstruction in Beirut and more generally Lebanon are the selectivity in its planning and the fragmentation in its implementation (figure 6). In other words, there was no overall plan, no cohesive vision for dealing comprehensively with matters related to war recovery. There was no planning ministry, and although the CDR did manage to fulfill many of the roles of such a ministry (some coordination of projects, funneling of funds from overseas for some rebuilding activities), these roles were never integrated into a unitary and visionary perspective, operating instead on the level of the revitalization of particular sectors or the study of particular parts of the country. The fragmentation of the reconstruction was thus both spatial and sectoral. At the same time, there was a double bias towards two types of physical schemes that dominated the plans that were put in place or the projects that were launched: major infrastructure and large-scale redevelopment of defined areas.

While some major infrastructure projects included complete new ventures that were constructed (such as the highway from Beirut to the South), many were pieces of projects, such as the erection of segments of new highways; for example, the bypass of the Damascus Road in the near suburbs of Beirut was built while awaiting a longer-term extension into the mountains. The partly damaged airport was totally rebuilt (at a scale that foresees a multiplication of the level of activity it receives nowadays); while the harbor received major refurbishment. The main park in the city, the Pine Forest (through which the demarcation passed during the war years), was unusual in that its reconstruction was subjected to a design competition, followed by implementation, although it is still (a decade later) waiting for its opening to the public. However, a crucial piece of planning such as the Transportation Plan that was prepared in 1994 by the French IAURIF agency remained largely a paper document. While some of the highways on it headed towards implementation, the rest of the (public) transportation improvements have not moved even partially towards reality.

As for the large redevelopment projects, there were three: the SOLIDERE project for the central district of Beirut; the Elyssar project for the phased total refection of the southern suburbs of Beirut, between the city limits and the airport; and the LINORD project for redeveloping Beirut's eastern coast and the Metn-Nord landfill just north of it. The betterknown and substantially realized first project is discussed later. The other two projects have had long, complex histories, with little to show on the ground a dozen years later. The Elyssar project, the closest one to a public redevelopment project of the three, was bogged down by political strife, lack of funding, complications in acquisition of lands and compensation of residents (legal and illegal), and many other challenges - this despite a gradual shift among local powerful groups (notably Hizbollah) from opposition to the project to integration into the shaping of it. Apart from a handful of new road segments in the area, nothing has been implemented, while life goes on for the tens of thousands of poor and 
middle-class residents that would have been impacted by the intended displacements and the subsequent collective housing that would have replaced this zone (Harb el-Kak, 2001, Clerc 2002). Meanwhile, the redevelopment of the eastern industrial zones has remained without any echo (apart from transformation on a case-by-case basis), whereas the northern landfills were stabilized and a grid of streets was laid out on them, but almost no construction has begun to fill in the large holes that are meant to become future city blocks (Verdeil, 2002b).

The three projects clearly differed from each other in many basic ways. Yet some key dimensions tied this trio of mega-projects together. The most obvious one is their scale, which set them apart from anything else that happened in the country in the 1990s - had the two suburban projects actually been implemented as intended. A second dimension is the principal driving characteristic of the projects as real estate projects, rather than as social transformation instruments or economic engines. At the same time, by their sheer size and by the values they represented, all the projects did acquire a symbolic significance. Finally, these are all not just long-term projects, but with histories that extended far into the past, as they built on many proposals and pieces of realizations that sought to transform through physical interventions these very areas dating back years or even decades, as was shown in the earlier sections of this paper.

The emphasis in this section on substantial plans and projects should not distract from the largely unplanned and non-project oriented reconstruction that characterized the postwar period in the country and its capital. The piecemeal nature of the reconstruction could be seen at two levels. As far as the war-damaged areas, while the central area given to SOLIDERE (and in a way the Pine Forest) are clearly subjected to a plan that was more or less followed, the far more substantial kilometers-long destruction along the line of demarcation was left to be recovered from according to the will and capacity of individual owners and renters. While refugees, displacees and others who suffered war losses did receive fairly fixed amounts from the government to help them recoup their losses, almost nothing more coordinated was undertaken in all these areas, all of which can be labeled reconstruction zones in the strictest sense of the term. Perhaps the lack of planning for the reconstruction along most of the demarcation line ${ }^{10}$ is more significant as a defining characteristic of the rebuilding of Beirut than the extremely controlled transformation that was applied to the kilometer or so of the demarcation line that fell within the SOLIDERE district. At the same time, the subdivision, development and redevelopment activity in the vast areas of Greater Beirut that cannot be considered as war-damaged areas was left entirely up to the individual property owners.

\section{SOLIDERE and its evolutions}

The creation of the SOLIDERE company as sole redeveloper of the partly war-destroyed central district of Beirut has been greatly publicized from the time of the controversies before its inception, through the regular features that appeared in the world (and local) press around the time of its launch and the start of its activities, until the recent years when its partial realization has become a sort of regional model for redevelopment ${ }^{11}$ and highlight of the touristic experience in Beirut. Given the mass of writings that exist on the subject, both

\footnotetext{
${ }^{10}$ A study by the IAURIF was prepared in the early 1990s, followed by some proposals that were meant to lead to a plan, but this was not pursued by the Lebanese government.

${ }^{11}$ As seen in references made in major redevelopment projects in Amman (Abdali) and Damascus (Souk Saruja) to SOLIDERE.
} 
scholarly (including by these authors) and in the mass media, ${ }^{12}$ and since this article made references to SOLIDERE throughout, the concluding section will be kept brief, reviewing retrospectively what characterized this approach to rebuilding Beirut's center, emphasizing the constants in the project and the aspects that evolved.

SOLIDERE's distinction is as a private, publicly traded corporation that was chartered by the Lebanese government (in the early 1990s) and was given full control over a clearly defined zone that covers Beirut's historic center and the immediately adjacent areas, including the massive trash dump on its seafront (about 1.5 square kilometers all together). The rights of most former property-owners and renters were transformed into shares, making up two thirds of the company's stock. The other third was opened to investors, local and Arab - the largest being Rafiq Hariri (the project has been intimately linked to the prime minister in reality and in the public imagination - figure 7). An old (unapplied) law allowing the creation of redevelopment corporations on the basis of land pooling and reparcelling had been used as basis for this approach, but it was modified to allow its combination with private investments and its treatment as a tradable company. The will to redevelop parts of the city center was a decades-old idea, as we have shown above, but the SOLIDERE route magnified this attempt in degree of control (from the clearance of entire sectors in the center, down to the choice of street pavement type), in scale (the redevelopment-area boundaries chosen went well beyond the area of heavy destruction) and in time (the state recently extended to 75 years the concession granted to SOLIDERE). Another innovative aspect of the project was the degree of professionalization of the company itself; indeed, its reliance on a state-of-the-art, technocratic approach in the planning, design, marketing, management and other processes was heavily emphasized in its self-representation, to emphasize to both the outside world and the country itself that it is meant as a model of the "world-class" globally integrated company that is possible in a Lebanon that is once again a vanguard of modernity in the Middle East.

While the dimensions above are the basic constants in SOLIDERE's history, the project has also evolved in various ways in the dozen years since the end of the fighting and the accession of Hariri to power in 1992 allowed it to move from paper ideas to concrete buildings, streets and spaces. The great degree of contestation that the concept of SOLIDERE as proposed faced soon after it was revealed had a range of impacts, including on the plans themselves. Two types of adjustments can be highlighted. In response to criticism of the mechanisms of expropriation and their consequences, a list was established of buildings that could be recuperated by their owners (hence excluded from the property-for-stock swap that was imposed on all others), to be renovated under strict controls of the company and within a strict timetable. All property held by religious communities (including under the waqf form of tenure) was also excluded. The broadest shift may have been the acceptance that certain sectors within the district were set aside as "historic" zones to be preserved but upgraded (figure 8). ${ }^{13}$ The repeated attacks by the project's initial critics, while they were not able to block the general approach the project adopted, can be largely credited for this subtle but important shift; some of these individuals have remained fully dissociated from SOLIDERE, by their choice or the company's, but others have ended up cooperating with it on a variety of bases, from planning or consulting on entire sectors within it to designing specific buildings inside its controls.

\footnotetext{
${ }^{12}$ See, for instance (in different languages): Beyhum, 1991; Cahiers de l’Orient, 1993-4; Khalaf and Khoury, 1993; 'Iimar bairut..., 1992; Schmid, 2002; Verdeil, 2002a.

${ }^{13}$ The resulting reduction in density was however amply compensated by increases in density elsewhere and an expansion of the landfill area.
} 
The integration of preservation - and to a lesser extent archeology - represented a partial shift towards the existing built fabric. However, this shift was very erratic, so some areas were totally (southern end of Burj Square), mostly (Souk Sursock/Souk Ayyas) or partially (Wadi Abu Jmil) razed, while others that had been equally impacted by the war were largely saved and renovated at great expense (Foch-Allenby, Etoile/Maarad, Saifi). This shift was accompanied by one in representation, where the modernity of the center was twinned with its historicity, as the company's former slogan of "ancient city for the future" crystallizes (Nasr, 1996). One sensed though that this shift was an effort at pacifying the critics. The renovation of the preserved areas was hence mostly a provision of an amenity for the rest of the center (and the city), which accounted for the bulk of the area and projected volume of construction. However, the slowdown in the economy and other reasons led to the preservation activities (and of course the completion of the main infrastructural works that had to be laid out first) largely preceding the new construction, which has seen a very slow start. The phenomenal success of the renovated areas - at least at ground level, as the upper levels remain largely a ghost town - has in fact transformed the meaning of the SOLIDERE precinct; ironically, the areas meant for larger buildings, which have so far mostly failed to materialize are actually providing the vast parking lots that serve the islands of fixed-up areas that have become the chief public space for all of Beirut (figure 9).

The slow start in the core activity of the company (the erection of thousands of square feet of new construction), as reflected in substantial loss of stock value and even reduction in personnel size over its first years of existence, is worth further consideration. Some of the explanations are internal to the approach followed. The choice of creating a world-class project has meant standards that have necessarily set the resulting cost per square meter far above those found in Beirut, thus excluding most from the possibility or renting, working, living or otherwise occupying the SOLIDERE zone (apart from as a space of leisure). Some of the costs have been dramatic, such as the stabilization of the trash dump and construction of the sea wall. The attitude of the company as an institution outside state controls (and above them) confronted realities of existing laws and regulations that fell under the purview of other governmental entities, which slowed down progress on a number of projects in the center; the relation to the Beirut municipality has been particularly problematic.

The impacts of these internal decisions blended with those of external factors, some more direct than others. Political positioning between the country's powerful groups and individuals often used SOLIDERE as a battleground. The main souks project, for instance, was originally seen as the initial catalyst and anchor for commercial activities in the district; instead, it is stalled as a consequence of conflicts between Hariri and some of his opponents controlling various state or municipal institutions. The project has thus missed the boat on the retail scene, which is scattering across other sites in the center as well as other neighborhoods in Beirut (Achrafieh, Verdun, Jnah...). The creeping economic slowdown in the country has probably had the most profound effects, for SOLIDERE as elsewhere. It can be partly to blame for the drop in the value of the company's stock, for a sizable deficit in its budget in 2000 , for a very slow take-off of its real estate sales, for cutbacks in its activities. While a new wave of investments emerged after September 11 $1^{\text {th }}$, 2001, these have not made up for the slowness of its start relative to what it had anticipated publicly.

As with most things in Lebanon, part of the political clash as it was translated into the battle over Beirut's center has had some sectarian dimensions. It is appropriate to conclude by considering how rebuilding Beirut's center has been about rebuilding a city in the Islamic world. One has to observe here that the confessional dimension has been largely absent from 
this section, and to some extent from most of the discussion of the many of the reconstructions of Beirut as proposed and planned in the past. In that way, this dimension has not dominated the rebuilding of Beirut's center. This does not mean an absence of religion as a factor of course. ${ }^{14}$ For one, the confessional communities have long been significant landowners and even developers in older parts of Beirut; but their role as a significant player was limited, and they were coopted as players, as SOLIDERE allowed their lands to be excluded from the land-pooling it undertook, and it distributed the representation on its board according to the various denominations, as is typically done in the highly confessionalized state of Lebanon.

The controversies that characterized the company's life, especially in its early years, rarely took explicitly sectarian dimensions. It is thus ironic that after all this time, it is only very recently that the first significant attempt at "Islamicizing" the city's center has gotten under way: the construction of the new great mosque in the very heart of the city, at the edge of the main square (el-Burj), adjacent to the main Maronite church of Saint George over which it is already towering (figure 10). The story of this mosque is complicated; suffice it to say that the introduction of the idea of a new great mosque, as had been erected in Casablanca, Amman and many other Arab (and other) cities, was originally in contestation of the authorities, but was then appropriated by these powers (and specifically Hariri). It may be then that, at a time when the reconstruction - and its correlation to a war that at least in part was about sectarian strife - is receding from the daily activities if not the memories in Lebanon, in the heart of the country's capital, religious symbolism is making its strong mark for the first time in the postwar period in one of the only parts of the city that had managed to avoid clear association with sectarian communitarianism.

\footnotetext{
${ }^{14}$ See for example Beyhum 1997.
} 


\section{List of References}

Beyhum Nabil, « 'Ne me tuez pas une seconde fois !' Note sur le mazar du Dimashki dit al Iraki dans le centre-ville de Beyrouth », in Beyrouth, regards croisés, M.F. Davie ed., 351353, Tours : URBAMA, 1997.

Beyhum Nabil, ed., Reconstruire Beyrouth: Les paris sur le possible. Collection Etudes sur le Monde Arabe, no. 5. Lyon: Maison de l'Orient Méditerranéen, 1991.

Cahiers de l'Orient (Les), special section on "La reconstruction du Liban", nos. 32-33, $4^{\text {th }}$ qu. 1993-1er trim. 1994.

Clerc Valérie, L'urbanisme face aux quartiers irréguliers. Le cas d'Elyssar en banlieue sud de Beyrouth, PhD dissertation, Paris VIII University, 2002.

Davie May, Beyrouth 1825-1975, Un siècle et demi d'urbanisme, Beirut : Ordre des ingénieurs et architectes, 2001.

Davie May, «Beirut and the "Etoile" Area: An Exclusively Colonial Project? » In Imported or Exported Urbanism?, ed. Joe Nasr and Mercedes Volait, 206-229. Chichester, UK: John Wiley \& Sons, 2003.

Debié Franck, Danuta Peter, La paix et la crise. Le Liban reconstruit, Paris, PUF, 2003.

Fawaz Mona, Strategizing for Housing: An investigation of the production and regulation mechanisms of low-income housing in an informal settlement in Beirut, forthcoming dissertation, Cambridge, Mass.: MIT.

Friedman Thomas L., From Beirut to Jerusalem, New York: Anchor Books/Random House, 1989, rev. ed. 1995.

Gavin Angus, Maluf Ramzi, Beirut Reborn, London: Academy Editions, 1996.

Ghorayeb, Marlène, « L’urbanisme de la ville de Beyrouth sous Mandat français, in « Figures de l'Orientalisme en architecture », C. Bruant, J. Leprun, M. Volait (eds.), Revue d'études sur le monde musulman et la Méditerranée, n73-74, 327-342, Aix-en-Provence : Edisud, 1996.

Hanssen Jens, « Your Beirut is on my desk », Ottomanizing Beirut under Sultan Abdül Hamid II (1876-1909), in Sarkis H. Rowe P., Projecting Beirut, Episodes in the Construction and the Reconstruction of the City, 41-67, New York Munich: Prestel, 1998.

Harb el-Kak Mona, "Urban Governance in Post-War Beirut: Resources, Negotiations, and Contestations in the Elyssar Project”, in SHAMI S. (dir.), Capital Cities: Ethnographies of Urban Governance in the Middle East, 111-133, Toronto: Toronto University Press, 2001.

Huybrechts Eric, Verdeil Eric, « Beyrouth entre reconstruction et métropolisation », in «Gouverner les métropoles », Villes en parallèle, n³2-33, pp.83-103, Nanterre : Editions de l'université Paris X-Nanterrre, 2000. 
'Iimar bairut wal-fursa al-da'iaa: wasat bairut al-tijari wal-sharika al-aaqaria: al-waqa'ii, al-murtakazat, al-bada'il. [The rebuilding of Beirut and the lost opportunity. The commercial center of Beirut and the real estate company: The realities, the assumptions, the alternatives]. Collective authorship (Nabil Beyhum, et al.). Beirut: Self-published, 1992.

Kasparian Chohig, L'entrée des jeunes Libanais dans la vie active, enquête réalisée par l'université Saint Joseph de Beyrouth, Beirut : Presses de l'Université Saint Joseph, 3 vol., 2003.

Kassir Samir, Histoire de Beyrouth, Paris : Fayard, 2003.

Khalaf Samir and Khoury Philip S., eds., Recovering Beirut: Urban Design and Postwar Reconstruction. Leiden: E.J. Brill, 1993.

Lettre d'information de l'ORBR, Beirut : CERMOC, 1994-2001, 14 issues.

Nasr Joseph L., "Beirut/Berlin: Choices in Planning for the Suture of two Divided Cities." Journal of Planning Education and Research, vol. 16, no. 1 (Fall 1996): 27-40.

Nasr Joseph L., "Reconstructing or Constructing Cities?: Stability and Change in Urban Form in Post-World War II France and Germany", Ph.D. dissertation, University of Pennsylvania, Philadelphia, 1997.

Nasr Joe, "Reconstruction." In Reconstruction et réconciliation au Liban: Négociations, lieux publics, renouement du lien social, ed. Eric Huybrechts and Chawqi Douayhi, 13-21. Cahier du CERMOC no. 23. Beirut: CERMOC, 1999.

Rowe Peter, Sarkis Hashim, eds. Projecting Beirut: Episodes in the Construction and Reconstruction of a Modern City. Munich, London and New York: Prestel, 1998.

Schmid Heiko, Der Wiederaufbau des Beiruter Stadtzentrums. Ein Beitrag zur handlungsorientierten politisch-geographischen Konfliktforschung, Heidelberg (Heidelberger Geographische Arbeiten, Bd. 114), 2002.

Tabet, Jad, ed. Reconstruction of War-Torn Cities, Proceedings of the UIA's International Conference, Nov. 1997. Beirut: Order of Engineers and Architects, 1999.

Tabet Jade et al., Portrait de ville : Beyrouth, Paris, Institut français d'architecture, 2001.

Verdeil Eric, « Reconstructions manquées à Beyrouth. La poursuite de la guerre par la projet urbain », Annales de la recherche urbaine, n91, 84-93, Paris-La Défense : Publications du Plan Urbanisme Construction Architecture, 2001.

| Verdeil Eric, Une ville et ses urbanistes: Beyrouth en reconstruction, PhD in Geography, Paris I University, 2002 (a).

Verdeil Eric, « Entre guerre et reconstruction, remblais et empiétements littoraux à Beyrouth », in Goeldner L., Velut S., Yellès-Baron N. (eds.), Le littoral. Mélanges en 
(b).

Verdeil Eric, « Politics, Ideology and Professional Interests: Foreign versus Local Planners in Lebanon under President Chehab » In Imported or Exported Urbanism?, ed. Joe Nasr and Mercedes Volait, 290-315. Chichester, UK: John Wiley \& Sons, 2003.

\section{List of illustrations}

Figure 1: Plan of the center of Beirut in 1912. Published in Palestine and Syria...Handbook for Travellers by Karl Baedeker, ${ }_{4}^{\text {th }}$ ed. Courtesy of the General Libraries, the University of Texas at Austin. Downloaded at http://www.lib.utexas.edu/maps/lebanon.html.

Figure 2: Proposal by Ernst Egli for transformations in Beirut and its suburbs, shown as part of an exhibit in 1950. Source : Egli collection, Archives of ETH-Zurich, Hs 785 : 142.

Figure 3: Project for changes in the central area of Beirut, by the Executive Council for Greater Projects in 1964. Consultants : M. Ecochard, G. Banshoya, A. Salam, P. el Khoury, N. Tabbara, R. Daoud, R. Issa. Source : photo E. Verdeil

Figure 4: Building destructions from the wartime period in the Metropolitan Area of Beirut. E. Verdeil@

| Figure 5: OGER project for the Martyrs Square area in 1984. Architect: Jean Willerval Source: Documentation center, CDR.

Figure 6: Reconstruction projects in the Metropolitan Area of Beirut during the 1990s. Source: Compiled by E. Verdeil. (c)

Figure 7: Poster for the Legislative Elections of September 2000, showing Rafiq Hariri in front of Maarad Street in Beirut's central district. Photo by E. Verdeil. @

Figure 8: Proposed plan for the central district of Beirut, as displayed in 1992? and 200?. Source: top, photo by J. Nasr ( ) ; bottom, photo by ???

| Figure 9: Overview of central district, showing the emptied out Martyrs' Square on right, and part of the ring road around the center on the left. Photo by E. Verdeil. ( $)$

Figure 10: New mosque under construction (March 2004) between Martyrs Square (al-Burj), in front, and St. George's Cathedral, to the left. At the far left is the Lazarieh complex, developed in the 1950 s on property owned by a religious institution. Photo by J. Nasr. (c) 